\title{
Technical Evaluation of a Dual- Junction Same-Band-Gap Amorphous Silicon Photovoltaic System at NREL
}

T. Strand, L. Mnig, R. Hansen, K. Emery

Prepared for the

First World Conference on Photovoltaic

Energy Conversion

December 5-9, 1994

Waikoloa, Hawaii

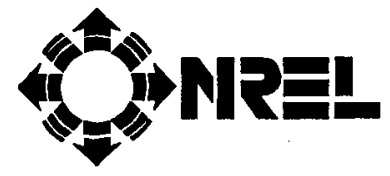

National Renewable Energy Laboratory 1617 Cole Boulevard

Golden, Colorado 80401-3393

A national laboratory of the U.S. Department of Energy Managed by Midwest Research Institute for the U.S. Department of Energy under contract No. DE-AC36-83CH10093

Prepared under Task No. PV460103

December 1994 


\section{NOTICE}

This report was prepared as an account of work sponsored by an agency of the United States government. Neither the United States government nor any agency thereof, nor any of their employees, makes any warranty, express or implied, or assumes any legal liability or responsibility for the accuracy, completeness, or usefulness of any information, apparatus, product, or process disclosed, or represents that its use would not infringe privately owned rights. Reference herein to any specific commercial product, process, or service by trade name, trademark, manufacturer, or otherwise does not necessarily constitute or imply its endorsement, recommendation, or favoring by the United States government or any agency thereof. The views and opinions of authors expressed herein do not necessarily state or reflect those of the United States government or any agency thereof.

Available to DOE and DOE contractors from:

Office of Scientific and Technical Information (OSTI)

P.O. Box 62

Oak Ridge, TN 37831

Prices available by calling (615) 576-8401

Available to the public from:

National Technical Information Service (NTIS)

U.S. Department of Commerce

5285 Port Royal Road

Springfield, VA 22161

(703) $487-4650$ 


\title{
TECHNICAL EVALUATION OF A DUAL-JUNCTION SAME-BAND-GAP AMORPHOUS SILICON PHOTOVOLTAIC SYSTEM AT NREL
}

\author{
Troy Strand, Laxmi Mrig, Robert Hansen, and Keith Emery \\ National Renewable Energy Laboratory \\ 1617 Cole Blvd., Golden, Colorado 80401, USA
}

\begin{abstract}
On December 7, 1992, a 1.8-kW $\mathrm{k}_{\mathrm{ac}}$ utility-interconnect photovoltaic (PV) system using amorphous silicon modules was brought on-line at the National Renewable Energy Laboratory's photovoltaic test site. This system was deployed to conduct an in-situ technical evaluation of the PV array (in a high voltage configuration) and system performance and reliability in a utility-interconnect application. The system is unique due to the installation of construction-grade insulation on the back of each PV module. This use of insulation is an attempt to levelize the annual array power output by elevating the operating temperature of the modules. This paper presents array and system performance data. Emphasis is placed on quantifying the effects of individual losses as well as seasonal changes on PV array and system performance.
\end{abstract}

\section{INTRODUCTION}

A 1.8-kW $\mathrm{kc}_{\mathrm{ac}}$ utility-interconnect photovoltaic (PV) system was brought on-line for technical evaluation at the National Renewable Energy Laboratory's (NREL) photovoltaic test site. The system is located at $39.7^{\circ} \mathrm{N}$ latitude, $105^{\circ} \mathrm{W}$ longitude, $1782 \mathrm{~m}$ elevation. The array is fixed at a $40^{\circ}$ tilt angle and is aligned true south. The PV array consists of six monopoles. The positive subarray comprises three monopoles and the negative subarray comprises the remaining three. Each monopole has 17 United Solar Systems Corp. (USSC) UPM-880 PV modules in series for a total of 102 modules. The modules are amorphous silicon (a-Si), with a dual-junction, same-band-gap structure and composition. The array output is fed to an Omnion Series 2200 static power converter rated at $2 \mathrm{~kW}_{\mathrm{ac}}$. The output of the power converter is fed to the local utility power grid via NREL's power distribution network. The system has been under evaluation since December 1992, with results being presented in previous publications [1]. Table 1 gives the array ratings at standard test conditions (STC): $1000 \mathrm{~W} / \mathrm{m}^{2}$, $25^{\circ} \mathrm{C}$, AM1.5 global spectrum.

The system was originally deployed as six monopoles of 16 UPM-880 PV modules in series totaling 96 modules. The ac output on March 24, 1993, was determined to be 1.65 $\mathrm{kW}_{\mathrm{ac}}$ at $1000 \mathrm{~W} / \mathrm{m}^{2}$ and $25^{\circ} \mathrm{C}$ back-of-module temperature. This output indicated that the system, as configured, did not meet the estimated system ac output of $1.8 \mathrm{~kW}_{\mathrm{ac}}$. Six additional modules were then added to the PV array on April 19, 1993 (one module per monopole), for a new total of 102 modules. This addition was an attempt to elevate the system's ac power output. The system was determined to be operating at $1.82 \mathrm{~kW}_{\mathrm{ac}}$ on August 24, 1993, and at $1.81 \mathrm{~kW}_{\mathrm{ac}}$ on August 17, 1994, at $1000 \mathrm{~W} / \mathrm{m}^{2}$, air mass 0.9 (corrected for pressure), and $25^{\circ} \mathrm{C}$ back-of-module temperature. As a consequence of adding the six additional modules, ac power and array peak power measured prior to April 20,1993, have been multiplied by the ratio of $102 / 96(1.0625)$ for this paper.

The Photovoltaic system was deployed to conduct an in-situ technical evaluation of the PV array and system performance and reliability in a utility-interconnect application. The system is unique due to the installation of construction-grade insulation on the back of each PV module. This use of insulation is an attempt to levelize the annual array power output by elevating the operating temperature of the modules. This paper presents array and system performance data. Emphasis is placed on quantifying the effects of individual losses as well as seasonal changes on PV array and system performance.

Table 1. Photovoltaic array ratings at STC

\begin{tabular}{|c|c|c|c|c|c|}
\hline $\mathrm{V}_{\mathrm{oc}}$ & $\mathrm{I}_{\mathrm{sc}}$ & $\mathrm{V}_{\operatorname{mx}}$ & $\mathrm{I}_{\max }$ & $\mathrm{P}_{\operatorname{mx}}$ & $\begin{array}{c}\text { Aperture } \\
\text { Area }\end{array}$ \\
\hline $\pm 374 \mathrm{~V}$ & $\pm 5.4 \mathrm{~A}$ & $\pm 265 \mathrm{~V}$ & $\pm 4.2 \mathrm{~A}$ & $2244 \mathrm{~W}$ & $37.59 \mathrm{~m}^{2}$ \\
\hline
\end{tabular}

EXPERIMENTAL PROCEDURE

The data acquisition system (DAS) is centered around a Campbell Scientific CR10 data logger. Data are sampled every $2.25 \mathrm{~s}$ (changed to $5 \mathrm{~s}$ on July 28,1994 ) and stored as hourly averages. Data collected include positive and negative dc currents and voltages; plane-of-array (POA) irradiance; ac current, voltage, and power; and back-ofmodule temperature. Meteorological data are provided by the Reference Meteorological and Irradiance Station (RMIS) located at the test site. The spectral and spatial optical properties of the atmosphere are measured and monitored by the Atmospheric Optical Calibration System (AOCS). 
Current versus voltage (I-V) traces are acquired monthly (weather permitting), at POA irradiance levels between 900 and $1100 \mathrm{~W} / \mathrm{m}^{2}$ (near solar noon), via a portable I-V curve tracer. The spectrum at the time of the I-V trace is either measured by a LiCor spectroradiometer or is calculated based on data from RMIS or AOCS. The spectral corrections used in this paper are based on the calculated spectrum. Prior to deployment, all modules had baseline I$V$ traces acquired both by a Spire $240 \mathrm{~A}$ solar simulator at STC and outdoors under prevailing conditions at NREL.

\section{RESULTS}

Figure 1 shows ac power (normalized to $1000 \mathrm{~W} / \mathrm{m}^{2}$ ) versus back-of-module temperature and time. The data set for this chart was restricted to POA irradiance levels greater than $750 \mathrm{~W} / \mathrm{m}^{2}$. The resulting data were then graphed and fit with sixth-order polynomial trend lines. Referencing these trend lines in the figure, a direct correlation among power, back-of-module temperature, and season is evident. This correlation is the well-documented seasonal change in performance exhibited by amorphous silicon PV modules $[2,3]$. The decrease in ac power output from the summer of 1993 high to the winter of 1993 low was approximately $7 \%$. The increase (rebound) in ac power output from the winter low of 1993 to the summer high of 1994 was approximately $6 \%$.

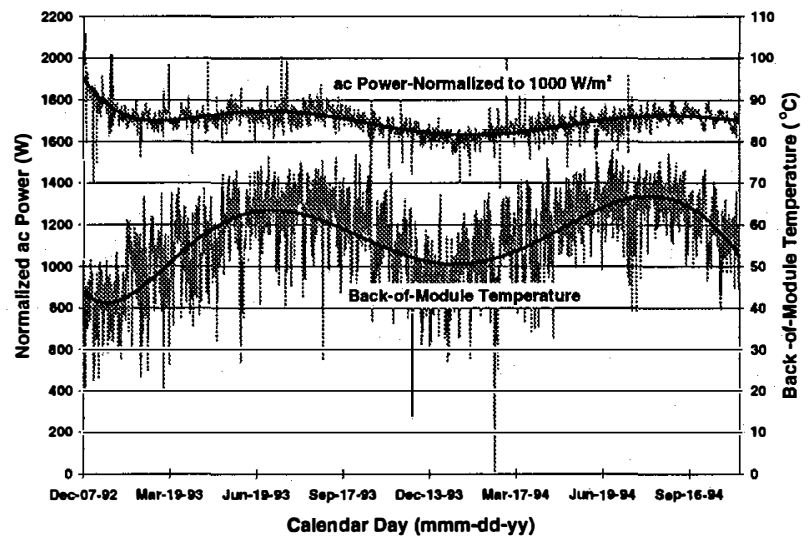

Figure 1. AC power normalized to $1000 \mathrm{~W} / \mathrm{m}^{2}$ versus back-of-module temperature and time

I-V traces of the PV array have been acquired monthly since system installation. Figure 2 presents the measured array peak power normalized to $1000 \mathrm{~W} / \mathrm{m}^{2}$ versus air mass, back-of-module temperature, and time. The array peak power on June 10, 1993 (summer of 1993 high), was $1902 \mathrm{~W}$. The array peak power on January 12, 1994 (winter of 1993 low), was $1744 \mathrm{~W}$. The array peak power on August 15, 1994 (summer of 1994 high), was 1933 W. From these values we see a decrease of $\approx 8.3 \%$ in array output from the summer of 1993 to the winter of 1993. Furthermore, an increase (rebound) of $\approx 10.8 \%$ in array output from the winter of 1993 to the summer of 1994 is also observed.
Given the seasonal changes in PV array and system performance, the focus was turned to quantifying the effects of temperature, spectrum, annealing, and light-induced degradation. In this regard, all known array losses and influences. on performance were either measured or calculated. The losses identified were module mismatch, system dc losses (i.e., wire, blocking diodes, switchgear, and protective fuses), and soiling. The influences on performance identified were changes in spectrum, temperature, and insolation.

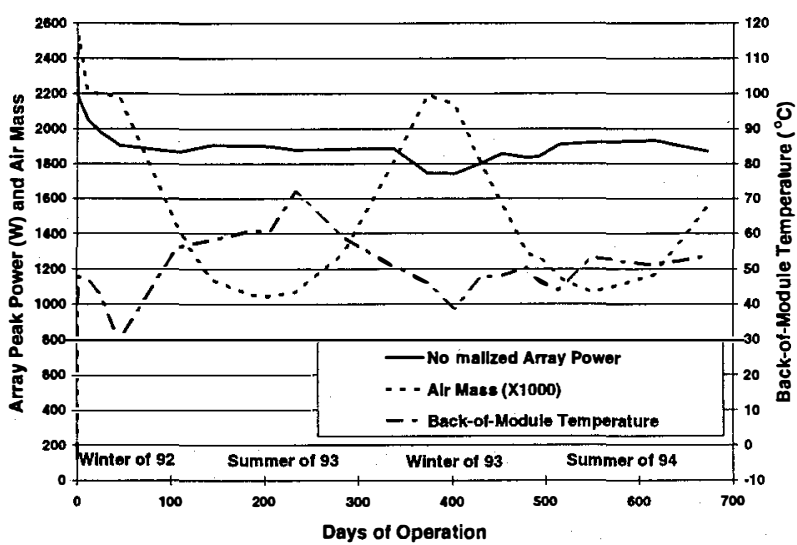

Figure 2. Array Peak power (normalized to $1000 \mathrm{~W} / \mathrm{m}^{2}$ ) versus air mass, back-of-module temperature, and time

The loss due to module mismatch was calculated based on the baseline I-V curve traces acquired via the Spire $240 \mathrm{~A}$ solar simulator and on each module's location in the PV array. Module mismatch was based upon the currentlimiting module (minimum $\mathrm{I}_{\text {MAX }}$ ) and the summation of $\mathrm{V}_{\text {MAX }}$ for each monopole. In determining the mismatch for each monopole, the product of the summation of $\mathrm{V}_{\text {Max }}$ and the minimum $I_{\text {MAX }}$ was divided by the summation of $P_{\text {MAX }}$. The mismatch calculated for all monopoles was then averaged. Module mismatch for the individual monopoles was calculated to range from $2 \%$ to $5 \%$. The module mismatch loss for the PV array was thus calculated to be approximately $3.6 \%$.

System dc losses were based on voltage drops measured at approximately $1000 \mathrm{~W} / \mathrm{m}^{2}$ and the calculated $I^{2} \mathrm{R}$ losses for all dc wiring. The voltage drops across each blocking diode, array fuses, and dc switch gear were measured. These voltage drops were then multiplied by the maximum power current (normalized to $1000 \mathrm{~W} / \mathrm{m}^{2}$ ) observed at the time of the I-V trace measurement and the results summed. The calculated resistance of the wire was multiplied by the square of the measured maximum power current (normalized to $1000 \mathrm{~W} / \mathrm{m}^{2}$ ). The system dc losses calculated in this manner were less than $10 \mathrm{~W}(0.3$ to 0.4 \%) at $1000 \mathrm{~W} / \mathrm{m}^{2}$ for this PV array.

To quantify the soiling losses, I-V curve traces of one monopole before cleaning (dirty) and after cleaning (clean) were acquired and compared at $1000 \mathrm{~W} / \mathrm{m}^{2}$. This method 
involved taking a "dirty" trace, cleaning the monopole, then immediately taking the "clean" trace. Soiling losses were measured at $3.2 \%$ on March 23,1993 , and $3.0 \%$ on October 28, 1994.

Using the modeled spectrum for the site at time of test, spectral corrections (based on the limiting cell of the dualjunction module: top, bottom, or matched) were calculated. To compare measured powers with respect to a specific reference spectrum (i.e., ASTM E892-87 global reference spectrum), the data must be corrected for the spectral mismatch error [4]. The spectral mismatch error was computed for each of the selected days using measured spectral response data from dual-junction same-band-gap amorphous silicon cells and modules of the same kind as deployed in the system. The spectral response of the reference device (pyranometer) is constant versus wavelength. The measured spectrum was problematic because the spectral irradiance was measured for only a few days and over a limited (300-1100-nm) spectral range. To solve this problem, the spectral irradiance was modeled using a semiempirical spectral model [5]. The model requires as inputs the POA tilt angle, air temperature, barometric pressure, measurement time, total irradiance on a horizontal surface, direct normal irradiance, the diffuse irradiance on a horizontal surface, and, preferably, the POA irradiance. All of these quantities were available. Figure 3 shows a comparison of the modeled spectrum with the spectral irradiance measured at NREL via a LiCor LI-1800 spectroradiometer on January 20, 1993. The spectral corrections (from summer to winter) obtained using this method ranged from $1.6 \%$ to $8.6 \%$ at the NREL PV test site. It should be noted that these spectral corrections are for current only and the fill factor will be influenced by other spectral effects.

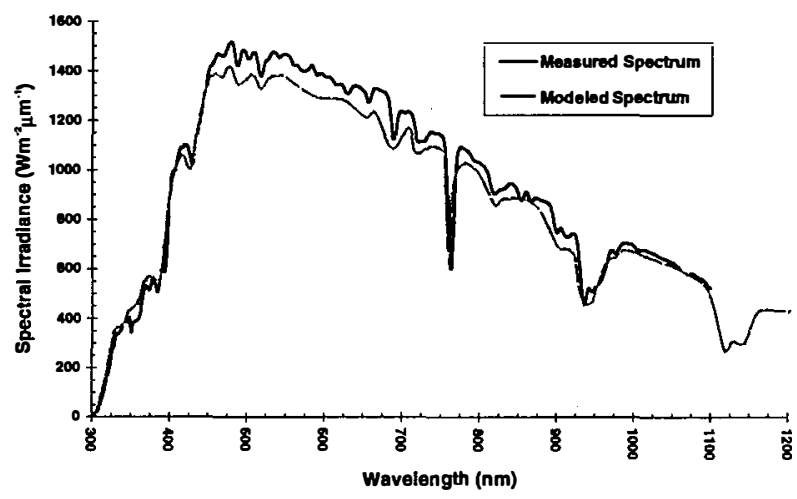

Figure 3. Measured spectrum versus modeled spectrum

Peak power was corrected for temperature based on a coefficient of $-0.1 \%$ per ${ }^{\circ} \mathrm{C}$. The temperature coefficient used for correcting peak power was that supplied by the manufacturer (USSC). For this analysis, it was assumed to be linear over the temperature range observed and independent of the spectrum. These corrections were then applied to the prevailing array peak power as measured by a portable I-V curve tracer.

The prevailing array peak power (normalized to 1000 $\left.\mathrm{W} / \mathrm{m}^{2}\right)$, changes in performance, and the previously listed losses were compared to the summation of rated module peak power at STC (102 modules $\times 22 W=2244 W$ ). Figure 4 presents the normalized array peak power, changes in performance, and losses as percent of the array rating at STC. Table 2 lists the data used in Fig. 4 in numeric format. The first few data points given in Table 2 are elevated due to the fact that the early light-induced degradation has not been fully completed. Consequently, the first six data points were not included in the results of this paper. After correcting the normalized peak power for temperature, spectrum, soiling, module mismatch, and dc system losses, the seasonal change in performance was still observed (see Fig. 4). The corrected array peak power decreased by $7.5 \%$ from the summer high on June 10 , 1993 , to the winter low on January 12, 1994. This decrease in array peak power, even after applying corrections, may be attributed to light-induced degradation. The corrected array peak power rebounded by $7.7 \%$ from the winter low on January 12, 1994, to the summer high on June 8, 1994. This rebound in corrected array peak power is attributed to thermally-induced annealing which appears to occur during the warm summer months.

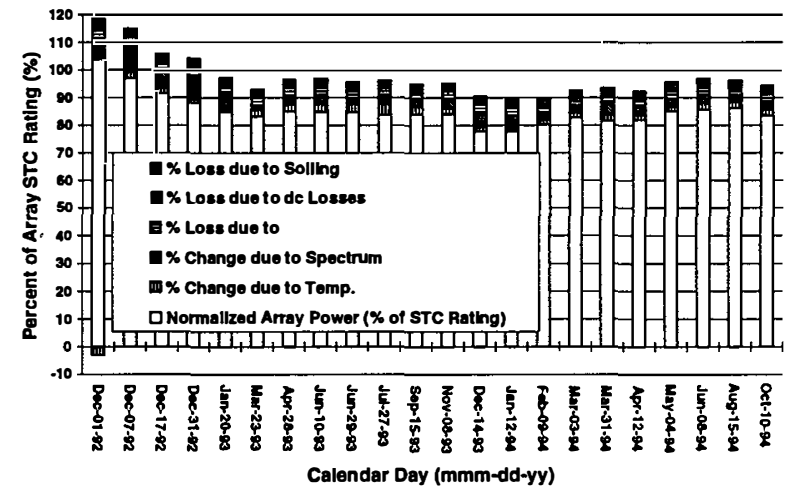

Figure 4. Normalized Peak Power and changes/losses compared to Array Peak Power at STC

Figure 4 shows that the peak powers measured on January 12, 1994, and June 8, 1994 (after applying corrections for the identified losses and changes in performance), were lower than the STC rating for array peak power by $10.8 \%$ and $3.1 \%$, respectively. This difference from the STC rating is attributed to measurement error (bias error), light-induced degradation, and annealing.

\section{CONCLUSIONS}

A 1.8-kW $\mathrm{K}_{\mathrm{ac}}$ a-Si dual-junction utility-interconnect PV system is operational and under evaluation at NREL's PV test site. The PV array and balance-of-system are performing as designed. 
Losses and changes in array performance were identified and quantified. System losses (dc only) were found to be less than $10 \mathrm{~W}$ for all data points. Losses due to soiling were measured at approximately $3 \%$. The loss due to module mismatch was calculated to be approximately $3.6 \%$. The change in performance due to temperature, from winter to summer, was found to range between $-3 \%$ and $+4 \%$. Changes in performance due to spectrum from summer to winter were found to be between $1.6 \%$ and $8.6 \%$. After correcting for these losses and changes, the measured (prevailing) array peak power was brought within approximately $11 \%$ of the STC rating for winter operation and $3 \%$ for summer operation.
The array peak power was found to degrade by $7.5 \%$ from summer to winter of 1993 and rebound (anneal) by $7.7 \%$ from the winter of 1993 to the summer of 1994. The lowest uncorrected array peak power, normalized to $1000 \mathrm{~W} / \mathrm{m}^{2}$ for the winter. of 1993 , was $77.7 \%$ of the $2244 \mathrm{~W}$ array peak power rating. The highest uncorrected array peak power, normalized to $1000 \mathrm{~W} / \mathrm{m}^{2}$ for the summer of 1994 , was $86.2 \%$ of the $2244 \mathrm{~W}$ array peak power rating.

As other mechanisms for system losses/degradation may affect the PV array, further research into the influences on array/system performance is being conducted.

Table 2. Array peak power (normalized to $1000 \mathrm{~W} / \mathrm{m}^{2}$ ), changes in performance, and losses compared to the STC rating for array peak power

\begin{tabular}{|c|c|c|c|c|c|c|c|c|c|c|}
\hline Date & $\begin{array}{c}\text { Limitting } \\
\text { Cell }\end{array}$ & $\begin{array}{c}\text { Spectral } \\
\text { Corr. }\end{array}$ & $\begin{array}{l}\text { Prevailing } \\
\text { Array Power } \\
\text { (\% of STC } \\
\text { Rating) }\end{array}$ & $\begin{array}{c}\text { Normalized } \\
\text { Array Power } \\
\text { (\% of STC } \\
\text { Rating) }\end{array}$ & $\begin{array}{c}\% \text { Change } \\
\text { due to } \\
\text { Temp. }\end{array}$ & $\begin{array}{c}\% \text { Change } \\
\text { due to } \\
\text { Spectrum }\end{array}$ & $\begin{array}{l}\% \text { Loss due } \\
\text { to Module } \\
\text { Missmatch }\end{array}$ & $\begin{array}{c}\% \text { Loss due } \\
\text { to dc } \\
\text { Losses }\end{array}$ & $\left|\begin{array}{c}\% \text { Loss due } \\
\text { to Soilling }\end{array}\right|$ & $\begin{array}{l}\text { Corrected } \\
\text { Array Power } \\
\text { (\% of STC } \\
\text { Rating) }\end{array}$ \\
\hline Dec-01-92 & TOP & 0.933 & 108.6 & 103.8 & -3.0 & 7.5 & 3.7 & 0.3 & 3.1 & 115.4 \\
\hline Dec-07-92 & TOP & 0.914 & 97.5 & 96.9 & 2.2 & 9.1 & 3.5 & 0.3 & 2.9 & 115.0 \\
\hline Dec-17-92 & TOP & 0.939 & 85.9 & 91.4 & 2.0 & 5.9 & 3.3 & 0.3 & 2.7 & 105.8 \\
\hline Dec-31-92 & TOP & 0.915 & 83.1 & 88.2 & 1.6 & 8.2 & 3.2 & 0.3 & 2.6 & 104.1 \\
\hline \begin{tabular}{|l|} 
Jan-20-93 \\
\end{tabular} & TOP & 0.933 & 86.2 & 84.9 & 0.4 & 6.1 & 3.1 & 0.3 & 2.5 & 97.3 \\
\hline Mar-23-93 & ВОТTOM & 0.984 & 85.2 & 83.2 & 2.6 & 1.4 & 3.0 & 0.3 & 2.5 & 93.0 \\
\hline Apr-28-93 & ВOTTOM & 0.968 & 85.2 & 85.0 & 2.8 & 2.8 & 3.1 & 0.3 & 2.5 & 96.5 \\
\hline \begin{tabular}{|l|} 
Jun-10-93 \\
\end{tabular} & BOTTOM & 0.966 & 81.9 & 84.8 & 3.0 & 3.0 & 3.1 & 0.3 & 2.5 & 96.7 \\
\hline \begin{tabular}{|l|} 
Jun-29-93 \\
\end{tabular} & ВОТTОМ & 0.976 & 82.4 & 84.6 & 3.0 & 2.1 & 3.0 & 0.3 & 2.5 & 95.7 \\
\hline \begin{tabular}{|l|} 
Jul-27-93 \\
\end{tabular} & ВOTTOM & 0.970 & 83.4 & 83.7 & 4.0 & 2.6 & 3.0 & 0.3 & 2.5 & 96.1 \\
\hline Sep-15-93 & ВOTTOM & 0.975 & 89.0 & 84.0 & 2.9 & 2.2 & 3.0 & 0.3 & 2.5 & 94.8 \\
\hline \begin{tabular}{|l|} 
Nov-08-93 \\
\end{tabular} & MATCHED & 0.967 & 81.1 & 84.1 & 2.2 & 2.9 & 3.0 & 0.4 & 2.5 & 95.1 \\
\hline Dec-14-93 & TOP & 0.933 & 76.4 & 77.8 & 1.7 & 5.6 & 2.8 & 0.3 & 2.3 & 90.5 \\
\hline \begin{tabular}{|l|} 
Jan-12-94 \\
\end{tabular} & TOP & 0.939 & 75.9 & 77.7 & 1.0 & 5.0 & 2.8 & 0.3 & 2.3 & 89.2 \\
\hline Feb-09-94 & MATCHED & 0.976 & 81.3 & 80.3 & 1.8 & 2.0 & 2.9 & 0.3 & 2.4 & 89.7 \\
\hline Mar-03-94 & ВOTTOM & 0.975 & 81.8 & 82.7 & 1.9 & 2.1 & 3.0 & 0.3 & 2.5 & 92.5 \\
\hline \begin{tabular}{|l|} 
Mar-31-94 \\
\end{tabular} & ВОтTOM & 0.953 & 85.7 & $81.7 \mid$ & 2.1 & 4.0 & 2.9 & 0.3 & 2.5 & 93.5 \\
\hline Apr-12-94 & ВОTTOM & 0.968 & $80.7 \mid$ & 82.0 & 1.8 & 2.7 & 3.0 & 0.3 & 2.5 & 92.3 \\
\hline May-04-94 & ВOTTOM & 0.966 & 81.7 & 85.1 & 1.6 & 3.0 & 3.1 & 0.3 & 2.6 & 95.7 \\
\hline Jun-08-94 & ВОTTOM & 0.967 & 79.8 & 85.6 & 2.4 & 2.9 & 3.1 & 0.3 & 2.6 & 96.9 \\
\hline Aug-15-94 & BOTTOM & 0.980 & 79.8 & 86.2 & 2.3 & 1.8 & 3.1 & 0.4 & 2.6 & 96.2 \\
\hline Oct-10-94 & ВOTTOM & 0.969 & $82.7 \mid$ & 83.4 & 2.4 & 2.7 & 3.0 & 0.3 & 2.5 & 94.3 \\
\hline
\end{tabular}

\section{ACKNOWLEDGMENTS}

The authors thank R. DeBlasio for his support and leadership of the Photovoltaic Module and System Performance and Engineering Project. We also thank B. Kroposki, D. Myers, J. Burdick, S. Rummel, L. Ottoson, and Y. Caiyem for their technical support. This work was supported by the United States Department of Energy under contract number DE-AC36-83CH10093.

\section{REFERENCES}

[1] T. Strand, L. Mrig, and R. Hansen, "Technical Evaluation of Photovoltaic Systems at NREL," PV Performance and Reliability Workshop, Lakewood, CO, September, 1994.

[2] R.G. Pratt and J. Burdick, "Performance of a $4 \mathrm{~kW}$ Amorphous-Silicon Alloy Photovoltaic Array at Oakland
Community College, Auburn Hills, Michigan," Twentieth IEEE PVSC, Las Vegas, NV, pp. 1272-1277, 1988.

[3] B. Kroposki and L. Mrig, "Thin Film Module Stability Testing at NREL," PV Performance and Reliability Workshop, Lakewood, CO, September, 1994.

[4] K.A. Emery, C.R. Osterwald, T.W. Cannon, D.R. Myers, J. Burdick, T. Glatfelter, W. Czubatyj, and J. Yang, "Methods for Measuring Solar Cell Efficiency Independent of Reference Cell or Light Source," Eighteenth IEEE PVSC, Las Vegas, NV, pp. 253-274, 1985

[5] S. Nann and C. Riordan, "Solar Spectral Irradiance under Clear and Cloudy Skies: Measurements and a Semiemperical Model," Jour. Appl. Meteorology, 30, pp. 447-462, 1991. 